\title{
The Influence Mechanism of Relationship Governance on Coordination Capability and Performance of Port Coal Supply Chain
}

\author{
Sha Beibei ${ }^{1, a}$ and Yang Bin ${ }^{2, b}$ \\ ${ }^{1}$ Business school, Macao University of science and technology, Macao, 999078, China \\ ${ }^{2}$ Bank of Langfang, Langfang, 065000, China \\ a148295827@qq.com, bbolyangbin@163.com
}

Keywords: trust, relational commitment, supply chain collaboration capability, supply chain performance

\begin{abstract}
This paper takes 63 port coal transportation enterprises in the Pearl-Xijiang River Basin as the research object, and tries to establish the structural equation Model (SEM) of the relationship between the inter-firm relationship management and the supply chain performance of the coal supply chain coordination capacity as the intermediary variable. In this paper, the empirical results show that trust is positively related to the commitment of relationship between port and coal transportation enterprises. Trust and relationship commitment are positively related to supply chain coordination ability. And the supply chain coordination ability is positively related to performance of enterprise supply chain. The results of the study support the conceptual model proposed in this study.
\end{abstract}

\section{Introduction}

The research on the factors influencing the supply chain coordination capability and performance is one of the hot topics in the supply chain field, which has been paid close attention and studied by scholars both at home and abroad in recent years. Emberson (2006) argues that the partnership between supply chain firms is the most typical factor. Li Suicheng et al. (2007) believes that the above indicators are also used in the study of the supply chain partnership capacity and B-S relationship on cooperation performance, but most of them are just conceptual theory and frame analysis, no in-depth analysis. Therefore, the paper choose 63 port coal enterprises in Zhujiang-Xijiang river basin as a research sample, and establishes the structural equation model between the above variables, and tested the research hypothesis raised, to verify the relationship between enterprises governance has an impact on the supply chain coordination capability and supply chain performance between the supply chain to supplement research the performance of the field theory, finally provide countermeasures and suggestions to improve the performance of supply chain enterprises.

\section{Variable relation, research hypothesis and theoretical model}

\subsection{Variable relation and research hypothesis.}

1) Trust and relationship commitment. Heide and John (1992) point out that pure contractual governance is inadequate because of the absence of key social factors. (2011) believe that environmental uncertainty will increase the impact of trust on supply chain performance, but will not affect the impact of contracts on supply chain performance. The method of trust can be subjected to certain environmental uncertainty through joint planning and joint problem solving.Chen et al. (2011) argue that trust is an important determinant of a relationship commitment that can only be accomplished if trust between partners is established. Therefore, this paper divides the relational governance process into two variables: trust and relationship commitment. Based on the above analysis, this study makes assumptions about the relationship between trust and commitment. 
H1. Trust between cooperative enterprises is positively related to relationship commitment.

2) Trust and supply chain collaboration capability. Liao Chenglin (2008) believes that the enterprise cooperation relationship has a significant positive correlation between the agile supply chain effect and the enterprise performance level. Supply chain synergy usually refers to the fact that two or more enterprises form a union, and the output is greater than the total output of the two firms. In port coal supply chain of China can achieve the supply chain collaboration is not much, but more and more enterprises are gradually accepted the idea that the establishment of trust between enterprises in the cooperation will have a win-win or win-win situation, which is an important development trend in the future in the field of supply chain. Based on the above analysis, this study proposes a hypothesis 2 about the relationship between trust and supply chain collaboration capability.

H2. Trust among cooperative enterprises is positively related to supply chain collaboration capability.

3) Relationship commitment and supply chain collaboration capability. Anderson et al. (1992) argue that firms and channels share goals and values, and that they have higher relational commitments that can work together more closely to achieve collaborative goals. Commitment will lead to an increase in intra channel collaboration, and will also enable supply chain enterprises to continuously improve their performance. Based on the above analysis, the hypothesis 3 of relationship commitment and supply chain collaboration capability is proposed.

H3. partnership commitment is positively related to supply chain collaboration capability;

4) Supply chain collaboration capability and supply chain performance. Partnership helps to improve supply chain performance (Luo \& Park, 2001; Luo,2003; Lorenzoni \& Fuller, 1995), For some domestic and foreign scholars collaborative ability to affect the performance of the supply chain in the supply chain, such as improving the performance of agile supply chain, supply chain quality improvement will have an impact on the performance of supply chain; supply chain coordination can improve supply chain performance, improve the overall competitiveness. However, the empirical research based on the port coal supply chain enterprises is very lacking. Based on the above analysis, the hypothesis 4 of upply chain collaboration capability and supply chain performance is proposed.

H4. supply chain collaboration capability among cooperative enterprises is positively related to supply chain performance.

\subsection{Theoretical model}

Comprehensive theoretical and empirical research on the above scholars at home and abroad, and the relationship between several variables hypothesis and the variables based on the definition of the logic model, it can basically determined the logic model of the trust, relationship commitment, supply chain performance and enterprise ability (shown in Fig. 1). In the logic model, trust and relationship commitment are independent variables, and enterprise supply chain performance is dependent variable, and supply chain collaboration capability is an intermediary variable

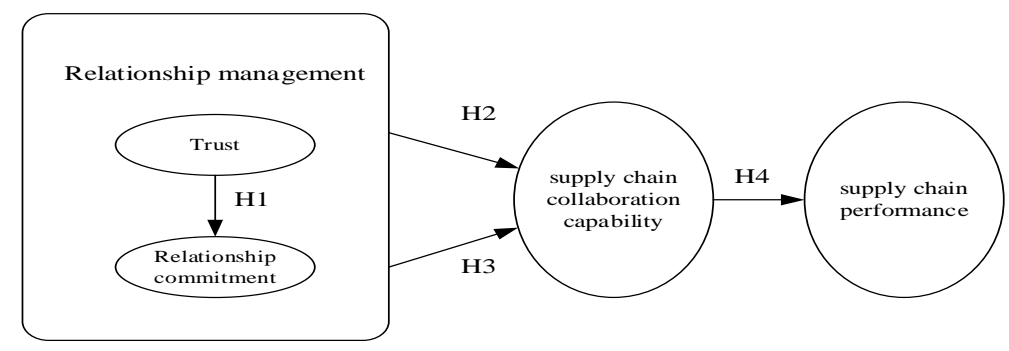

Fig. 1. Logic model 


\section{Research methods}

\subsection{Variable definition.}

In order to ensure the reliability and validity of the measurement tool, the measurement tools used in this study refer to the scales validated and used by the majority of scholars and make appropriate changes according to the actual research needs. There are five factors in the trust scale: the relationship commitment scale has six factors; the supply chain coordination capacity scale has six factors; the supply chain performance scale of the eight factors are Y1 Y8 for the trust, cooperation Commitment, reliance, innovation learning, internal processes, users, financial perspective.

\subsection{Analysis and statistical methods.}

The data of this study were analyzed by SPSS12.0 and LISREL 8.53 statistical software package. Including: (1) reliability and validity analysis: The reliability index used in this study is based on Cronbach's $\alpha$ coefficient as a measure of internal consistency. (2) factor analysis: the use of principal component analysis method of eigenvalues (Eigenvalue) is greater than 1 factors, and the use of maximum variation of the axis of rotation to the axis of rotation to shorten the original data facets, but can still maintain or explain the original data provided Most of the features. (3) Linear Structural Equation (SEM): After testing by confirmatory factor analysis, if the questionnaire can meet the criteria for testing, a linear structural relationship (LISREL) can be used to detect the structural model. The purpose of this model is to identify variables Between the causal relationship.

\section{Empirical results and analysis}

\subsection{Reliability and validity analysis.}

Reliability refers to the stability and consistency of the results measured by the measurement tool. The reliability index used in this study is based on the Cronbach's alpha coefficient as a measure of the internal consistency of the question. The reliability of this study is shown in Table 1 . In the test table, the t-value between the individual question and its multi-construct must reach a significant level to represent the scale with the convergence validity. In this study, the load factor of each measurement variable is between 0.70 and 0.90 , and the factor load t-value is between 8.10 and 12.35, which is significant, as shown in Table 2. Therefore, the measurement model has the convergence validity.

Table 1 . The reliability analysis

\begin{tabular}{|c|c|c|c|}
\hline Variable & $\begin{array}{c}\text { Measured topic } \\
\text { number }\end{array}$ & $\begin{array}{c}\text { Cumulative } \\
\text { explanation ability }\end{array}$ & Cronbach's $\alpha$ \\
\hline Trust & 5 & $56.473 \%$ & 0.754 \\
\hline $\begin{array}{c}\text { Relationship } \\
\text { commitment }\end{array}$ & 6 & $53.368 \%$ & 0.732 \\
\hline $\begin{array}{c}\text { Supply chain } \\
\text { collaboration capability }\end{array}$ & 6 & $62.117 \%$ & 0.685 \\
\hline $\begin{array}{c}\text { Supply chain } \\
\text { performance }\end{array}$ & 8 & $51.223 \%$ & 0.732 \\
\hline
\end{tabular}

\subsection{Factor analysis.}

According to the factors analysis of the research conducted by trust, relationship commitment, four aspects of supply chain coordination capability and supply chain performance, looking for correlations between items, in order to test, based on the original cut or variable, as the basis for model updating. The results of the factor analysis in this study is shown in Table 1.5 items are extracted in trust, including all factors of load reached more than 0.5 , there were $56.473 \%$ cumulative explanation. 6 items extracted in the relationship commitment, accumulated interpretation ability is $53.368 \%$. 6 items extracted in the supply chain coordination ability, the 
ability to explain the cumulative $62.117 \% .8$ items are extracted in the supply chain performance, accumulation ability to explain 51.223\%.

\subsection{Linear structure analysis.}

In this study, the adaptation criterion for the structured whole model is estimated by using the maximum likelihood approach, and the whether observed level of fit between the data obtained and the theoretical formula at 0.05 is achieved. According to the T estimation of the parameter value, and examine each hypothesis whether there is significant, if the t value is greater than 1.96 , then that has a $95 \%$ confidence interval, $t$ if the value is greater than 2.58 , then there are $99 \%$ confidence interval. The measurement model is the confirmatory factor analysis (CFA). CFA must be based on a specific theoretical or conceptual framework, and then the mathematical program to confirm whether the derived measurement model is true. Measurement of path coefficient were adjusted model in this study, as shown in Table 2.

Table 2. Adjusted model path coefficient

\begin{tabular}{|c|c|c|c|}
\hline Variable & $\begin{array}{l}\text { Measuring } \\
\text { project code }\end{array}$ & $\gamma_{\text {value }}$ & t-value \\
\hline \multirow{5}{*}{ Trust } & $\mathrm{X} 1$ & $0.86 * * *$ & 8.56 \\
\hline & $\mathrm{X} 2$ & $0.73 * * *$ & 8.38 \\
\hline & X3 & $0.76 * * *$ & 8.66 \\
\hline & $\mathrm{X} 4$ & $0.82 * * *$ & 9.26 \\
\hline & X5 & $0.71 * * *$ & 8.68 \\
\hline \multirow{6}{*}{$\begin{array}{l}\text { Relationship } \\
\text { commitment }\end{array}$} & X6 & $0.84 * * *$ & 8.86 \\
\hline & $\mathrm{X7}$ & $0.83 * * *$ & 8.34 \\
\hline & $\mathrm{X} 8$ & $0.86 * * *$ & 9.26 \\
\hline & X9 & $0.72 * * *$ & 8.29 \\
\hline & $\mathrm{X} 10$ & $0.81^{* *}$ & 8.48 \\
\hline & $\mathrm{X} 11$ & $0.79 * * *$ & 12.35 \\
\hline \multirow{6}{*}{$\begin{array}{c}\text { Supply chain } \\
\text { collaboration } \\
\text { capability }\end{array}$} & $\mathrm{X} 12$ & $0.84 * * *$ & 9.16 \\
\hline & X13 & $0.93 * * *$ & 8.31 \\
\hline & X14 & $0.86 * * *$ & 8.56 \\
\hline & X15 & $0.92 * * *$ & 9.19 \\
\hline & $\mathrm{X} 16$ & $0.81 * * *$ & 11.18 \\
\hline & $\mathrm{X} 17$ & $0.89 * *$ & 12.31 \\
\hline \multirow{8}{*}{$\begin{array}{l}\text { Supply chain } \\
\text { performance }\end{array}$} & Y1 & $0.88 * * *$ & 8.16 \\
\hline & Y2 & $0.73 * * *$ & 9.11 \\
\hline & Y3 & $0.84 * * *$ & 8.51 \\
\hline & Y4 & $0.72 * * *$ & 9.39 \\
\hline & Y5 & $0.91 * * *$ & 8.78 \\
\hline & Y6 & $0.78 * * *$ & 8.10 \\
\hline & Y7 & $0.91 * *$ & 8.58 \\
\hline & Y8 & $0.79 * * *$ & 8.37 \\
\hline
\end{tabular}

The assumed empirical results and causal path coefficient of model are shown in Table 3 . In the evaluation of causal path coefficient, path coefficient is mainly including: $\gamma 11$ refers to the trust relationship commitment path coefficient; $\gamma_{21}$ refers to the trust on supply chain coordination ability of the path coefficient; $\gamma_{31}$ refers to the path coefficient of relationship commitment on supply chain coordination ability; $\beta 11$ refers to the supply chain coordination the ability of supply chain performance path coefficient.

From table 3 we can know the coal port enterprises, supply chain management in the trust relationship commitment have significant effects $\left(\gamma_{11}=0.85, \mathrm{t}=3.11\right)$, $\mathrm{p}$-value has reached a significant level, so H1 up. Trust on supply chain coordination ability is also significantly affected ( $\gamma$ 21=0.92, $\mathrm{t}=3.61)$, p-value also reached significant level, so H2 up. We can see that the unity of 
commitment and collaboration of supply chain collaboration between port coal enterprises is very important, at the same time, the supply chain enterprises to meet the level of trust in supply chain coordination requirements and development is also very important, so we can through relationship commitment management, allow enterprises to reduce from supply chain coordination capabilities. At the same time, the port coal enterprise relationship commitment to the supply chain coordination ability has significant effects $\left(\gamma_{31}=0.77, \mathrm{t}=3.76, \mathrm{H3}\right)$ is established, through the implementation of the port coal enterprise relationship management, can quickly grasp real-time supply situation, timely adjustment between the degree of elastic and low port coal enterprise logistics risk.

Table 3. The assumed empirical results

\begin{tabular}{|c|c|c|c|c|}
\hline $\begin{array}{c}\text { Research } \\
\text { hypothesis }\end{array}$ & Variables relationship & $\begin{array}{c}\text { Path } \\
\text { coefficient }\end{array}$ & t-value & $\begin{array}{c}\text { Empirical } \\
\text { results }\end{array}$ \\
\hline H1 & $\begin{array}{c}\text { Trust- Relationship } \\
\text { commitment }\end{array}$ & 0.85 & $3.11^{*}$ & up \\
\hline H2 & $\begin{array}{c}\text { Trust- Supply chain } \\
\text { collaboration capability }\end{array}$ & 0.92 & $3.61^{*}$ & up \\
\hline H3 & $\begin{array}{c}\text { Relationship commitment- } \\
\text { Supply chain collaboration } \\
\text { capability }\end{array}$ & 0.77 & $3.76^{*}$ & up \\
\hline H4 & $\begin{array}{c}\text { Supply chain collaboration } \\
\text { capability -Supply chain } \\
\text { performance }\end{array}$ & 0.68 & $2.04^{*}$ & up \\
\hline Note: $(1) *$ means p<0.05
\end{tabular}

In the port of coal supply chain enterprises conduct trading activities, good supplier management can be through the supply chain coordination ability, performance significantly affected ( $\beta$ 11=0.68, $\mathrm{t}=2.04)$, $\mathrm{p}$-value has reached a significant level, so H4 up. The ability of coordination of port coal enterprise's supply chain can increase in trust, cooperation, commitment, dependence, innovation and learning, internal processes, customer, financial and other aspects, among the silent prior to reach port of coal enterprises. So can reduce the occurrence of coal transportation in the course of time, the price of goods timeliness is not balanced, the coal transportation process and low cost, high yield, high reliability and fast delivery has direct effect.

This study tested the model fitting degree, is to test the impact of trust and relationship commitment, and the supply chain collaboration capability on supply chain performance. After LISREL analysis, the overall model fitting degree evaluation is shown in Table 4.

Table 4.The overall model fitting index

\begin{tabular}{|c|c|c|c|c|c|}
\hline $\begin{array}{c}\text { Fitting } \\
\text { index }\end{array}$ & $\mathrm{X}^{2}$ & $\mathrm{df}$ & $\mathrm{X}^{2} / \mathrm{df}$ & RMSEA & GFI \\
\hline Value & 51.010 & 51 & 1.000 & 0.001 & 0.933 \\
\hline $\begin{array}{c}\text { Fitting } \\
\text { index }\end{array}$ & AGFI & NFI & CFI & PNFI & PGFI \\
\hline Value & 0.962 & 0.965 & 0.985 & 0.681 & 0.714 \\
\hline
\end{tabular}

\section{Conclusion and significance}

Through building structural equation model among trust, relationship commitment and supply chain collaboration capability and enterprise supply chain performance, the empirical results show that the strengthening of trust relationship commitment has a significant positive effect to enhance trust. Strengthen the supply chain coordination ability improvement has significant positive effects. Similarly, promotion of the supply chain relationship commitment have significant positive effects on the improvement of supply chain collaborative capacity. At the same time, the supply chain coordination ability has a significant positive effect on the enterprise supply chain performance. In addition, there is no direct impact among enterprise trust, relationship commitment and enterprise 
supply chain performance, but indirectly through the intermediary variables of supply chain coordination ability affecting the performance of the enterprise supply chain.

\section{References}

[1] Emberson C, Storey J. Buyer-supplier collaborative relationships: beyond the normative accounts [J]. Journal of Purchasing \&Supply Management, 2006, 12 (5): 236-245.

[2] Petersen K J, Ragatz G L, Monczka RM. An examination of collaborative planning effectiveness and supply chain performance [J]. TheJournal of Supply Chain Management, 2005,41 (2): 14-25.

[3] Li Suicheng, Zhang Zhe. Analysis of the influence of supply chain cooperation level on supply and demand cooperation performance under uncertainty [J]. science and technology management research, 2007 (5): 85-87

[4] Heide J B, John G.Do norms matter in marketing relationships[J].Journal of Marketing, 1992, 56(2):32-44.

[5] Macneil I R.The New Social Contract: An Inquiry into Modern Contractual Relations[M].New Haven, CT:Yale University Press, 1980: 46. 